\title{
Everyday Renaissances: The Quest for Cultural Legitimacy in Venice
}

Review Number: 2087

Publish date: Thursday, 30 March, 2017

Author: Sarah Gwyneth Ross

ISBN: 9780674659834

Date of Publication: 2016

Price: $£ 39.95$

Pages: 256pp.

Publisher: Harvard University Press

Publisher url: http://www.hup.harvard.edu/catalog.php?isbn=9780674659834

Place of Publication: Cambridge, MA

Reviewer: Thomas Goodwin

On the 18th of June, 1556, Mr Francesco, a second-hand goods dealer with a shop near the clock tower in Piazza San Marco, borrowed two Greek manuscripts from the collection that would later become the heart of Venice's famous Marciana library: Proclus on Platonic Theology, and The Commentary of Hierocles on the Golden Verses of Pythagoras. As collateral for the loan, he left an engraved silver basin. (p. 3)

Why did a second-hand goods dealer want to borrow two works of philosophy written in Greek? Why did he want them in manuscript form, when at least one of them (Proclus) was available in print? Should his borrowing of these texts be seen as a strategy for attaining cultural capital, in the Bordieuan sense - or is this an overly reductive assessment of his motivations? How usual was it for non-elites to demonstrate this sort of interest in classical and humanist literature, and what is the place of quantitative methodologies in investigations of this and related topics in the social history of ideas? These are some of the questions that Sarah Gwyneth Ross raises in her thought-provoking new book on 'everyday Renaissances' and the quest for what she calls 'cultural legitimacy' in 16th-century Venice.

Everyday Renaissances represents the latest contribution to recent efforts at blurring the lines between the social and intellectual history of Renaissance Italy, which has so far yielded particularly fruitful research concerning the impact of humanistic culture and education beyond the world of 'professional' or 'literary' humanists. To date, such studies have tended to focus on 15th-century Florence. A pioneering example in this regard was Lauro Martines's monograph, The Social World of the Florentine Humanists, published in 1963, which demonstrated the potential for a social history of humanism based principally on quantitative analysis, drawing in his case on extraordinarily rich 15th-century Florentine tax records.(1) However, studies in the social history of ideas have generally not followed Martines's lead with regard to methodology, in that they have largely eschewed quantitative approaches. Ross cites, as an example of this reticence, Robert Darnton's influential view that 'cultural objects are not manufactured by the historian but by the people he studies. They give off meaning. They need to be read, not counted'.(2) In contrast Ross argues, quite reasonably, that such an approach 'risks keeping the spotlight on those who left substantial documentary trails, which often meant the privileged' (p. 14). 
One of the strengths of Everyday Renaissances is hence the way in which Ross balances quantitative and qualitative approaches to her subject in an effort to study people who, in her words, 'valued learning and literature', but 'whose intellectual lives were not coterminous with their gainful employment' (p. 1). In doing so, she calls into question the traditional view of Venetian humanism advanced by Margaret King, among others, as essentially a patrician phenomenon.(3) In contrast, Ross shows that humanist culture had a much more wide-ranging influence on Venetian society than has conventionally been believed. Contrary to what might be induced from focussing on writings by humanists themselves, and from the careers of famous humanist patricians like Pietro Bembo, Venetian elites appear to have been far less interested in amassing collections of literature and practicing what Ross calls 'testamentary humanism' than university-educated cittadini such as priests, lawyers and especially physicians - as well as some artisans like the aforementioned Mr Francesco. Indeed, despite their absence from the title, the perspective of educated physicians on humanist culture is the main focus of Everyday Renaissances and the strongest part of its thesis - all three of its case studies are physicians, along with the subjects of many of the other wills and inventories surveyed. Ross argues persuasively that 'physicians consistently demonstrated themselves both most inclined to exploit the discursive potential of the testament and to harbor book collections that outpaced those of patricians by order of magnitude, and even those of their near relatives on the professional family tree - priests, lawyers, secretaries - by significant margins' (p. 10). This is backed up by a wealth of evidence from wills, funeral orations, published works, private journals, household inventories, and so on, which comprehensively demonstrates the anxiety surrounding social status that physicians felt in this period and the importance of demonstrating humanist - that is, non-medical - learning in addressing said anxiety.

Another central theme of Everyday Renaissances is Ross's concept of 'cultural legitimacy'. Cultural legitimacy is presented as a more flexible version of Bourdieu's idea of cultural capital, now widely referenced by social historians, although perhaps not so often engaged with critically. In Ross's view, '[Bourdieu's] concept privileges too much the ultimate conversion of intellectual, literary, and artistic possessions and commitments into literal social and economic rewards' (p. 5). On the other hand, 'cultural legitimacy embraces the potential of that socio-economic conversion ... but ...[it] was not only about practical gain and social positioning. Intellectual and literary values had a power that was not always measurable, let alone monetary' (p. 5). Thus cultural legitimacy is intended to make room for education and culture being ends in themselves, as well as a means of socioeconomic advancement. I am not sure, however, whether Bourdieu's approach is really as focused upon practical gain, upon measurability, as Ross seems to imply. Surely his distinction between cultural and economic capital is intended to create a space for entirely immaterial effects of some forms of cultural capital, such as educational attainment? He even argues, for instance, that 'the structure of the distribution of economic capital is symmetrical and opposite to that of cultural capital'. (4) Moreover, Ross's model invites the question: how far can historians really determine whether historical actors are pursuing education or culture in of themselves, or as means of socioeconomic advancement?

Everyday Renaissances is split into two parts, which deal respectively with the macro - an overview of Venice's reading public and the evidence for 'testamentary humanism' - and the micro - case studies of the literary lives of three members of Venice's College of Physicians. The first chapter of part one is an overview of the world of literary consumption in 16th-century Venice, building most particularly on Marino Zorzi's study of 16th-century Venetian book ownership, which was based on an analysis of records from the Cancelleria Inferiore and the Giudici di Petizion.(5) Ross's findings, however, differ in important ways, drawing on a slightly larger sample that also includes some records from the Archivio IRE, a collection of documents relating to charitable institutions including book bequests. (pp. 29-30)

Based on her analysis of a total of 1,227 inventories, Ross's sample yields 101 book owners, of which 34 were patricians. Of the remainder, 28 per cent are 'retail merchants' or artisans, which is in strong contrast with Zorzi's finding of five per cent. (p. 32) Unlike Zorzi, Ross also breaks down her results for cittadini by profession. 40 per cent of Zorzi's sample were simply classed as cittadini, whereas Ross's sample includes 13 clergymen, 14 lawyers and secretaries, and 11 physicians. 'Those affiliated with medicine', by which 
Ross means physicians, 'health practitioners', pharmacists, and barber-surgeons - constitute 27 per cent of the sample. (p. 32) Another interesting statistic explored in this chapter is the median number of books owned by members of different professions. Ross finds that physicians had the largest collections on average with a median of 140 books, while the average size of lawyers' libraries was 120 books, and 92 was the average number of books owned by priests (p. 36). Surprisingly, retail merchants and artisans owned 11-12 books on average, suggesting that Mr Francesco's literary interests were not as anomalous as they might first appear. Patricians, on the other hand, owned a median of only 32 books (pp. 36-7).

Ross does a wonderful job of weaving into this quantitative analysis the tantalising glimpses into the world of non-elite book ownership that household inventories can provide. One such example is a goldsmith's wife whose inventory recorded eight books, included works by Lucan, Josephus, Ariosto, and Marcus Antonius Sabellicus (p. 38). Another is that of a pharmacist's widow who owned copies of Augustine's Confessions, Orlando Innamorato, and Orlando Furioso (p. 39). Overall, this chapter does demonstrate that the 'reading public' for classical literature in 16th-century Venice was wider than we have generally believed - as much as 18 per cent of her inventories mention 'books for reading' - as well as making a strong case that members of professions such as the law, the clergy and above all, medicine, displayed a greater engagement with the world of humanist culture than we have assumed. (p. 31) However, one criticism that must be made here is that, in her analysis of these inventories, Ross does not take into account research into contemporary reading practices. As Roger Chartier has observed, inventories made after death often only refer to books sufficiently valuable to be 'thought worth mentioning', such as for example where such items were intended to be sold at public auction; moreover, it gives no indication of books that were more commonly borrowed rather than owned, or, perhaps most crucially, that people may have heard someone else read.(6) At one point Ross remarks that 'an important direction in the history of the book would be circulation of texts and borrowing practices outside the ranks of eruditi' (p. 38). Indeed, to study book culture in this period, an awareness of the historicity of reading practices and book ownership is crucial, and is something that Ross perhaps does not pay sufficient attention to in this chapter.

The second chapter of Everyday Renaissances is devoted to an examination of the wills of practitioners of 'testamentary humanism' - Ross's loosely-defined term for testators who in their wills made direct literary references, referred to literary or pedagogical endeavours, made book bequests, provided money for the education of relatives, or used the opportunity to offer ethical advice. Ross argues that this was a widespread practice, again more so among cittadini than among patricians. Inspired by recent work on Christian and Jewish 'ethical wills', Ross has combed testaments for 'not only the rare cases of testators who made direct literary references but also testators who mentioned their own literary or pedagogical endeavours'; or otherwise evidenced what she considers to be humanistic preoccupations, such as lectures to their successors on ethics that appear to be more foregrounded in notions of classical virtù than the Christian variety (pp. 523).(7) According to Ross, these testators were not following an established humanist style of will-making, as none existed. Rather, 'testamentary humanists' were exploiting 'more fully the discursive potential of the testament as document, a desire we find most among the people who did not have the access to literary expression that humanists enjoyed' (p. 53). On the other hand, just two per cent of the 3,005 wills examined by Ross meet her criteria for 'testamentary humanism' (p. 72). She points out, in mitigation, that 'testamentary humanists' were writing these literary wills despite explicit legal discouragement from doing so - citing for instance an influential treatise by Francesco Mantica discouraging 'superfluity' - but it is surely significant, nevertheless, as regards these testators representativeness.

It is certainly clear that some testators saw humanist education as an effective way of overcoming social stigma. A particularly eye-opening example is the case of a priest, Paulo Pincio, whose son Felippo had the considerable misfortune to be born not only illegitimate, but also the son of a priest, and an unimportant one at that (even the famous Cardinal Pietro Bembo, as Ross reminds us, had great difficulty in securing a future for his illegitimate children) (pp. 57-8). Pincio exhorts Felippo to 'attend to your studies ... bearing in mind that it falls to you to maintain the honor of this family'. By doing so, his father concludes, 'you will earn honor and profit and, in the end, you will be dear to God and to men' (p. 58). Other wills likewise raise interesting questions regarding contemporary views on the relationship between education and masculinity, 
and especially on the capacity of study to turn a young man into a uomo da bene, a slippery term variously translated as a 'good man' or a 'man of the right sort' (pp. 59-60). Some testators even threatened to disinherit their sons entirely for poor academic performance (pp. 64-5). Intriguingly, this picture strongly contrasts with evidence from patrician's wills in which, Ross suggests, humanist education is portrayed less as a means of self-fashioning than as a way of learning refined social graces (pp. 70-1).

In the second half of the book Ross moves from the macro to the micro. Each of its three chapters is a case study of an individual member of Venice's College of Physicians in the 16th century, exploring the different ways in which each of them primarily engaged with humanist culture through publications, 'philosophical testaments', and private journals. The first concerns Nicolò Massa (1485-1569), who, Ross argues, aimed at securing humanistic recognition for medicine as a liberal art in his published writings. Ultimately, he was very successful in securing recognition for himself, at least, becoming the only physician afforded a sentence in Francesco Sansovino's Delle cose notabili della città di Venezia, a veritable who's who of 16th-century Venice. Massa was described as 'a celebrated physician and philosopher of exceeding broad wisdom' (p. 79).(8) Like many contemporary writers, Massa was extremely clever in his use of paratexts, especially dedicatory letters and prefaces strewn with references to Virgil, Homer and Plato, as a means of expressing his humanist learning and patronage connections (pp. 84-5).

The second case study is Francesco Longo (1506-76) which draws upon his draft will of 1552 and his final will of 1574. In this chapter, Ross argues that whereas Massa can be seen using his literary interests strategically in order to gain cultural capital, Longo's goals are rather more idealistic. Ross demonstrates the influence of Stoicism in Longo's personal moral philosophy and his apparently lifelong interest in holding up the Persian king Artaxerxes as a moral exemplar (pp. 115-18). It is perhaps here that her argument that education and culture was sometimes seen as a goal in of itself rather than a means of socioeconomic advancement is at its most forceful, given that Longo does not seem to have expressed his philosophical interests outside of these two wills. On the other hand, her references to his extensive use of patronage networks while a student at the University of Padua, and an investigation during his matriculation into whether or not Longo was eligible to join the College of Physicians, given his family background (his father had been a pharmacist, and membership of the College was reserved for cittadini) seem to suggest, again, the use of education for pragmatic purposes (pp. 127-8).

Lastly, Ross examines the journals of Alberto Rini (d. 1599). It was common for physicians, along with many other sorts of people at the time, to record the minutiae of everyday life using journals, and certainly Rini is careful to meticulously record the public achievements of his family. However, as Ross shows, his journals also contain a great deal of evidence of Rini's intellectual interests. His wonderfully eclectic journals include collections of recipes (including medicinal ones from books of secrets, which educated physicians like Rini were supposed to refrain from doing); appreciations of art; commentary on current affairs; and demonstrate, above all, his great interest in books. Rini enjoyed copying out sermons and histories by hand, and records his interactions with the humanist Paolo Ramusio from whom he borrowed manuscripts of the chronicles of Doge Andrea Dandolo, as well as amassing a large personal library (p. 150-1). However, the significance of Rini's desire to read texts in manuscript and to copy them out himself - as with Mr Francesco's desire to borrow Greek philosophical texts in manuscript, rather than consulting the available printed editions - is never really addressed. Moreover, although it is certainly clear from these case studies that physicians remained anxious about their social and intellectual status well into the 17th century - rather than until the end of the 15th century, as was previously thought - it is unclear whether Ross believes that there are any significant changes in their attitude to literature and education over the course of the 16th century, despite the fact that she examines the literary lives of individuals drawn from across the period.

These criticisms aside, Ross has done a wonderful job of demonstrating the interest in literature and philosophy of people who have normally been excluded from the history of Venetian humanism, by means of an extensive use of sources usually ignored by intellectual historians. She has shown the receptiveness of physicians, in particular, to humanist culture in 16th-century Venice, as well as raising important questions 
regarding the humanist interests of patricians, and consequently, regarding the supposedly elitist nature of Venetian humanism. Her deft blend of quantitative and qualitative approaches ought to become a model for future contributions to the social history of ideas. Her critique of Bourdieu is certainly interesting - though I am unconvinced that cultural capital will be superseded by cultural legitimacy. Nevertheless, Everyday Renaissances is undoubtedly an important, innovative and thought-provoking contribution to the social, cultural and intellectual history of Renaissance Italy, and ought to become essential reading for anyone interested in the wider impact of humanism on Italian culture.

\section{Notes}

1. Lauro Martines, The Social World of the Florentine Humanists, 1390-1460 (Princeton, NJ, 1963). Back to (1)

2. Robert Darnton, The Great Cat Massacre and Other Episodes in French Cultural History (New York, NY, 1984), p. 258. Back to (2)

3. See, most particularly, Margaret L. King, Venetian Humanism in an Age of Patrician Dominance (Princeton, N.J., 1986).Back to (3)

4. Pierre Bourdieu, Distinction: A Social Critique of the Judgement of Taste, trans. Richard Nice (London, 1984), p. 120.Back to (4)

5. Marino Zorzi, 'La circolazione del libro a Venezia nel Cinquecento. Biblioteche private e pubbliche', Ateneo Veneto, 177 (1990), 117-89.Back to (5)

6. Roger Chartier, 'Reading matter and 'popular' reading: from the Renaissance to the seventeenth century', in A History of Reading in the West, ed. Guglielmo Cavallo, Roger Chartier, and Lydia G. Cochrane (Oxford, 1999), p. 270.Back to (6)

7. See, for example, Stanley Chojnacki, Women and Men in Renaissance Venice: Twelve Essays on Patrician Society (Baltimore, MD, 2000); Hebrew Ethical Wills, ed. Israel Adams (Philadelphia, PA, 2006). Back to (7)

8. Francesco Sansovino, Delle cose notabili della città di Venezia (Venice, 1596), p. 124.Back to (8)

\section{Other reviews:}

\section{$\mathrm{H}-\mathrm{Net}$}

https://networks.h-net.org/node/7651/reviews/168591/carnelos-ross-everyday-renaissances-quest-culturallegitimacy-venice [2]

Open Letters Monthly

http://www.openlettersmonthly.com/book-review-everyday-renaissances/ [3]

Source URL:https://reviews.history.ac.uk/review/2087

\section{Links}

[1] https://reviews.history.ac.uk/item/251485 [2] https://networks.hnet.org/node/7651/reviews/168591/carnelos-ross-everyday-renaissances-quest-cultural-legitimacy-venice [3] http://www.openlettersmonthly.com/book-review-everyday-renaissances/ 